\title{
Identification of keratinophilic fungi in the coat microbiota of anteaters retained in captivity in two Brazilian Zoos
}

\author{
Identificação de fungos queratinofílicos na microbiota do pelame de tamanduás mantidos em \\ cativeiro em dois zoológicos no Brasil \\ Identificación de hongos queratinofílicos en la microbiota del pelaje de osos hormigueros en \\ cautiverio en dos zoológicos en Brasil
}

Henri Donnarumma Levy Bentubo ORCID: https://orcid.org/0000-0003-0091-2504 Universidade Paulista, Brasil Universidade do Vale do Paraíba, Brasil E-mail: hbentubo@yahoo.com.br Giselle Silva Moreira ORCID: https://orcid.org/0000-0002-4922-6807 Universidade Paulista, Brasil E-mail: gi.vet.2017@gmail.com.br

Cátia Dejuste de Paula

ORCID: https://orcid.org/0000-0001-9769-4915 Universidade Federal Fluminense, Brasil E-mail: cdejuste@gmail.com

Flávia Regina Miranda

ORCID: https://orcid.org/0000-0002-3804-3781 Grupo de Trabalho pela Conservação do Tamanduá no Brasil, Brasil Universidade Estadual de Santa Cruz, Brasil

E-mail: flaviamiranda@yahoo.com

Selene Dall'Acqua Coutinho ORCID: https://orcid.org/0000-0001-9715-6500 Universidade Paulista, Brasil E-mail: selene@uol.com.br

\begin{abstract}
Anteaters comprise three different species: Myrmecophaga tridactyla (flag anteater), Tamandua tetradactyla (mini anteater) and Cyclopes didactylus (anteater), some considered vulnerable to extinction. These species are distributed over a large part of the Brazilian territory, especially in the cerrado biome. In order to preserve these species, some research work on the health status of these animals has been carried out, both in captive and free-living animals. The objective of this study was to investigate keratinophilic filamentous fungi, including dermatophytes, in the coat of 27 adult anteaters retained in captivity. Among the animals studied, 14 were giant anteater (Myrmecophaga tridactyla) and 13 were small anteater (Tamandua tetradactyla). These specimens were retained at the São Paulo Zoological Park Foundation and Quinzinho de Barros Municipal Zoological Park. Samples were obtained by means of rubbing sterilized squares of carpet on the coat of each animal. Each carpet was seeded in Petri dishes containing Mycobiotic $^{\mathrm{TM}}$ agar medium (Difco ${ }^{\mathrm{TM}}$ ) and incubated at $25^{\circ} \mathrm{C}$ until colony growth was observed. Dermatophytes were not isolated; however, the following genera of filamentous fungi were identified: Cladosporium spp. (51.8\%), Scopulariopsis sp (29.6\%), Aspergillus spp. (22.2\%), Acremonium spp. and Chrysosporium spp. (11.1\%) and Mucor spp. (7.4\%), among these we highlight the keratinophilics: Scopulariopsis sp, Acremonium spp. and Chrysosporium spp. There are few studies on the prevalence of dermatophytes and other keratinophilics in wild animals and none on anteaters. It was possible to confirm the presence of non-dermatophytic keratinophilics in the normal microbiota of anteaters, similarly to what was observed in other mammals.
\end{abstract}

Keywords: Anteaters; Scopulariopsis sp; Chrysosporium spp.; Acremonium spp.

\section{Resumo}

Os tamanduás compreendem três diferentes espécies: Myrmecophaga tridactyla (tamanduá-bandeira), Tamandua tetradactyla (tamanduá-mirim) e o Cyclopes didactylus (tamanduaí), algumas consideradas vulneráveis à extinção. Essas espécies estão distribuídas em grande parte do território brasileiro, especialmente, no bioma cerrado. Na intenção de preservar essas espécies algum trabalho de pesquisa sobre o status sanitário desses animais têm sido realizados, tanto em animais cativos como em vida livre. O objetivo do presente trabalho foi pesquisar fungos filamentosos queratinofílicos, entre eles, dermatófitos, no pelame de 27 tamanduás adultos mantidos em cativeiro. 
Entre os animais estudados, 14 eram da espécie tamanduá-bandeira (Myrmecophaga tridactyla) e 13 eram tamanduásmirim (Tamandua tetradactyla). Esses espécimes eram mantidos na Fundação Parque Zoológico de São Paulo e Parque Zoológico Municipal Quinzinho de Barros. As amostras foram obtidas por meio da fricção de quadrados de carpete esterilizados no pelame de cada animal. Cada carpete foi semeado em placas de Petri contendo meio de ágar Mycobiotic $^{\circledR}\left(\right.$ Difco $\left.^{\circledR}\right)$ e incubado a $25^{\circ} \mathrm{C}$ até que se observasse crescimento das colônias. Não foram isolados dermatófitos do pelame dos animais estudados, contudo, foram identificados os seguintes gêneros de fungos filamentosos: Cladosporium spp. (51,8\%), Scopulariopsis sp (29,6\%), Aspergillus spp. (22,2\%), Acremonium spp. e Chrysosporium spp. (11,1\%) e Mucor spp. (7,4\%), dentre esses destacamos os queratinofílicos: Scopulariopsis sp, Acremonium spp e Chrysosporium spp. Existem poucos trabalhos sobre a prevalência de dermatófitos e demais queratinofílicos em animais selvagens e nenhum sobre tamanduás. Foi possível confirmar a presença de queratinofílicos não-dermatófitos na microbiota normal de tamanduás, à semelhança do observado em outros mamíferos.

Palavras-chave: Tamanduás; Scopulariopsis sp; Chrysosporium spp.; Acremonium spp.

\section{Resumen}

Los osos hormigueros comprenden tres especies diferentes: Myrmecophaga tridactyla (oso hormiguero bandera), Tamandua tetradactyla (mini oso hormiguero) y Cyclopes didactylus (oso hormiguero), algunas consideradas vulnerables a la extinción. Estas especies se distribuyen en gran parte del territorio brasileño, especialmente en el bioma del cerrado. Con el fin de preservar estas especies, se han realizado algunos trabajos de investigación sobre el estado de salud de estos animales, tanto en cautiverio como en libertad. El objetivo del presente trabajo fue investigar los hongos filamentosos queratinofílicos, incluidos los dermatofitos, en el pelaje de 27 osos hormigueros adultos mantenidos en cautiverio. Entre los animales estudiados, 14 eran oso hormiguero gigante (Myrmecophaga tridactyla) y 13 eran oso hormiguero pequeño (Tamandua tetradactyla). Estos ejemplares se conservaron en la Fundación del Parque Zoológico de São Paulo y en el Parque Zoológico Municipal Quinzinho de Barros. Las muestras se obtuvieron frotando cuadrados esterilizados de alfombra sobre la piel de cada animal. Cada alfombra se sembró en placas de Petri que contenían medio de agar Mycobiotic ${ }^{\circledR}\left(\right.$ Difco $\left.^{\circledR}\right)$ y se incubó a $25^{\circ} \mathrm{C}$ hasta que se observó el crecimiento de la colonia. No se aislaron dermatofitos del pelaje de los animales estudiados, sin embargo, se identificaron los siguientes géneros de hongos filamentosos: Cladosporium spp. (51,8\%), Scopulariopsis sp (29,6\%), Aspergillus spp. (22,2\%), Acremonium spp. y Chrysosporium spp. (11,1\%) y Mucor spp. $(7,4 \%)$, entre ellos destacan los queratinofílicos: Scopulariopsis sp, Acremonium spp. y Chrysosporium spp. Hay pocos estudios sobre la prevalencia de dermatofitos y otros queratinofílicos en animales salvajes y ninguno en osos hormigueros. Se pudo constatar la presencia de queratinofílicos no dermatofitos en la microbiota normal de osos hormigueros, de manera similar a lo observado en otros mamíferos.

Palabras clave: Osos hormigueros; Scopulariopsis sp; Chrysosporium spp.; Acremonium spp.

\section{Introduction}

Biodiversity is essential for the survival of humanity and its intrinsic and extrinsic value has been widely recognized by means of governments and civil society in several international agreements (Peres et al, 2011). It is believed that in Brazil there are approximately 1.8 million known species among plants and animals, of which 210 thousand are invertebrate and vertebrate animals distributed in 541 species of mammals, 1696 species of birds and more than 5000 species including reptiles, amphibians and fishes. This number is much higher according to estimates by means of Lewinsohn and Prado (2005). The Brazilian fauna is one of the largest and most important in the world, corresponding to $13 \%$ of the world's biota divided into biomes: Amazon Forest, Atlantic Forest, Caatinga, Cerrado, Pantanal and Campos Sulinos (Benites \& Mamede, 2008) and its loss is one of the worst current global crises, with species and habitats decreasing at an alarming rate as ilustrated since 2008 by means of the Red List of Endangered Species of some national and international preservation institutions (Vié et al, 2009).

The intense environmental degradation has fragmented forests where more than a half of the cerrado area has been transformed into pastures or grain plantations (Rambaldi \& Oliveira, 2005; Klink \& Machado, 2005). According to the Biodiversitas Foundation: "One of the biggest challenges for governments is the definition of strategic plans for the conservation of biodiversity" (Fundação Biodiversitas, 2010), since human activity can lead to environmental degradation and compromise the survival of species (Fundação Zoo-botânica, 2000). Professionals from numerous areas of the science, governmental and non-governmental organizations, including veterinarians, biologists and environmentalists have dedicated a large effort to the conservation of endangered species and this effort is translated through increasing studies and researches in 
the area of the national flora and fauna. Some institutions such as the International Union for the Conservation of Nature (IUCN) have created lists (IUCN "Red List") based on worldwide research and databases to define endangered species and it works for the conservation of these species around the world (IUCN, 2021).

IUCN is a union of partners composed exclusively of governmental and civil society organizations in which it provides public, private and non-governmental organizations with the knowledge and tools that enable human progress, economic development and nature conservation to occur together (IUCN, 2021). The update of the "Red List" carried out in September 2017 placed the giant anteater on a scale of least concern (IUCN, 2021); the small anteater and the silky anteater did not enter the list, revealing that the efforts made have had a positive result (Project Tamanduá, 2015). In Brazil, organizations such as the Instituto Brasileiro do Meio Ambiente e Recursos Naturais Renovaveis (IBAMA) and the Instituto de Pesquisa e Conservação do Tamanduá no Brasil (Projeto Tamanduá) carry out different works for the conservation and development of these and other endangered species. IBAMA is a government institution linked to the Ministerio do Meio Ambiente (MMA) created in 1989 with the aim of exercising the power of federal environmental police with an important role in environmental licensing, environmental quality control, authorization for the utilization of natural resources and inspection, monitoring and environmental control (IBAMA, 2017) in which it works together with non-governmental organizations such as the Projeto Tamanduá, which aims to preserve animals that have been thus little studied in this case, the Anteaters, Armadillos and Sloths (Xenarthra); developing research in the wild, working in partnership with national and international screening centers and zoos, developing a database and biological samples, acting strongly in public policy actions with the Brazilian government (Projeto Tamanduá, 2015).

Three species of anteaters are currently known, natives of the Brazilian cerrado and belonging to the order Xenarthra, of the Myrmecophagidae family, Myrmecophaga trydactyla (giant anteater), Tamanduá trydactyla (small anteater) e o Cyclopes didactylus (silky anteater) from the family Cyclopedidae (Cubas et al, 2014). These animals are solitary mammals with twilight habits, their body color is dark gray mixed with white, the fore limbs are whitish and the hind limbs are black (Vieira, 1949 \& Braga, 2010). They can reach more than two meters in length and weigh more than $39 \mathrm{~kg}$ (Wetzel, 1985; Eisenberg, 1989; Drummond, 1994; Braga, 2010). They have nails that measure up to $6.5 \mathrm{~cm}$, important structures for their diet according to Carvalho (1996) and Braga (2010), as they assist to open anthills and termite mounds and moreover as a defense (Rossoni et al, 1981, Braga, 2010; Nowak, 2018); in addition to having a series of morphological adaptations such as the absence of teeth and well-developed salivary glands, as well as the tongue, which can extend up to $61 \mathrm{~cm}$ outside the mouth (Rossoni et al, 1981; Chebez, 1994; Emmons, 1997, Braga, 2010, Nowak, 2018, Teta et al, 2018). Its diet is exclusive to insects, mainly from the orders Hymenoptera (ants) and Isoptera (termites) (Montegomery, 1985; Shaw et al, 1985; Medri et al, 2003 \& Zimbres, 2010).

As Rosa (2007) states: "The giant anteater has energy limitations due to its energy-poor diet, thus it has some characteristics to compensate for these limitations, such as low metabolism and low temperature and thermal conductance". Temperature and dietary restriction have been depicted as stressors for rabbits, influencing the immune response (Franci et al., 1996; Acco, 1999). Among the main stressors for wild and domestic animal species are physical containment and transport, which are therefore utilized as models of stressors in research (Morton et al., 1995 \& Acco, 1999). These and other innovations such as confinement, change the temperament and behavior of animals, contributing to the incidence of stress on the species (Bispo \& Pereira, 1994; Carramenha, 2012) in addition to threats to the survival of these species through predatory hunting, roadkill, the loss of its habitat due to gradual deforestation due to agricultural expansion, fires and animal trafficking, a definitely common practice in underdeveloped countries (IUCN, 2021; IBAMA, 2016; Projeto Tamanduá, 2015). It is known that animals in captivity may demonstrate considerable differences in their microbiota because, according to Acco (1999), the stress of confinement can influence animal behavior and possibly the immune response of animals in captivity. As it is a 
specimen of wild habits, it could suffer from a probable infection due to contact with fomites contaminated with the presence of opportunistic fungi in the environment (even if the enclosure undergoes disinfection processes) developing eventual skin diseases.

Fungi are microorganisms belonging to the Fungi Kingdom, classified into Chytridiomycetes, Zygomycetes, Ascomycetes and Basidiomycetes, composed of eukaryotic cells that present DNA surrounded by means of a nuclear membrane; they can be unicellular (yeasts) or pluricellular (mushrooms), classified as saprobes (dependent on dead organic matter) or biotrophic (dependent on living organic matter), widely dispersed in the environment and additionally present in the microbiota of humans and animals (Paula et al. , 2007). According to Paula et al (2007), most of these fungi develop at a pH close to 6.0 and a temperature between $25^{\circ} \mathrm{C}$ and $30^{\circ} \mathrm{C}$; are easily sown in culture media where their growth and form varies according to the type of fungus: molds (hyphae-forming filamentous fungi), yeasts (spherical non-filamentous fungi) and dimorphic ones (they have both forms of growth - usually pathogenic fungi) . Fungi reproduce asexually and sexually, are of extreme ecological importance since they are found in tree trunks, plants, soil and other organic materials, widely utilized in the pharmaceutical and food industries and some with pathogenic characteristics, which is why biologists have classified the fungi in the seventies creating the Kingdom Fungi, which is divided into three groups: slime fungi, inferior flagellate fungi and terrestrial fungi that include: mushrooms, yeasts and molds (Lacaz, et al, 2002). There are few studies on the prevalence of dermatophytes in wild animals and none on anteaters in this way, the present study consists of researching the presence of dermatophytes and other potentially pathogenic keratinophilic fungi in captive anteater coat in order to assist and expand the conservation of the considered species vulnerable to extinction (IUCN, 2021).

Based on the scarcity of studies on the health aspect of wild animals, as well as some important predictive microbiological parameters for disease prevention, monitoring and even therapeutic interventions, the aim of this study was to investigate the possible presence of dermatophytes and other filamentous fungi with keratinophilic nature as resident and/or transient members in the surface microbiota of the integument of two of the three species of anteaters maintained as a biomaterial reserve in conservation institutions in Brazil.

\section{Methodology}

\subsection{Samples}

In the present study, 27 animals were utilized, including giant anteaters and anteaters, all from the Fundação Parque Zoológico de São Paulo (FPZSP), located in the city of São Paulo; Quinzinho de Barros Municipal Zoological Park (PZMQB), located in Sorocaba-SP; and a specimen from the Pantanal Mato-grossense which, at the time this research was carried out, was contained and submitted for evaluation in field activity by means of the Working Group for the Conservation of Anteater in Brazil (GTCT). Of these, 14 individuals were giant anteaters (Myrmecophaga tridactyla) and 13 are small anteaters (Tamandua tetradactyla), all specimens in their adult phase, with the predominant situation being captivity.

\subsection{Sample collection and processing}

After physical restraint of the animals, coat samples were obtained by means of rubbing previously sterilized squares of carpet over the back of each animal. They were sent aseptically and under refrigeration to the Laboratory of Molecular and Cell Biology (UNIP), where they were seeded, by means of printing, in Petri dishes containing Mycobiotic ${ }^{\mathrm{TM}}$ agar (Difco ${ }^{\mathrm{TM}}$ ) and incubated at $25^{\circ} \mathrm{C}$. Each plate was inspected every two days for four weeks or until growth of filamentous fungal colonies was noted (Mariat \& Adam-Campos, 1967, Bentubo et al, 2006; Bentubo et al, 2021). 


\subsection{Identification of fungi}

The filamentous fungi obtained in the cultivation of samples collected from the skin of the specimens studied were identified by means of their macro and microscopic morphological characteristics. To verify the macroscopic characteristics, giant colonies were produced in Petri dishes containing the same medium utilized for the priming isolation. To obtain preparations that allowed the analysis of the microscopic morphology of the isolates, a classical method based on the microculture slide technique was utilized (Riddel, 1950). Taxonomic manuals were utilized as a reference for comparing the visible structures in the macro and microscopy of the isolates (Kurtzman \& Fell, 1998; De Hoog et al, 2004).

\section{Results and Discussion}

Research works related to the health aspects of wildlife animals are still quite limited. The scientific community's concern with the environment and the required conserve endemic fauna has stimulated pioneering initiatives across the country. This is the case of the Working Group for the Conservation of Anteaters in Brazil (Projeto Tamanduá), which is based at the São Paulo Zoological Park Foundation (FPZ-SP), has the mission of promoting actions that favor the conservation of anteater species in Brazil. Through a scientific collaboration established between Projeto Tamanduá and the Laboratory of Molecular and Cell Biology (LBMC) at Universidade Paulista (UNIP), where the CLININFEC (Research Group in Clinical and Infectious Diseases, registered with the $\mathrm{CNPq}$ ) is furthermore headquartered and the phase of experimental studies of the present research.

The technique of the square of carpet rubbed over the back, originally depicted by means of Mariat \& Adam-Campos (1967) to obtain samples for the isolation of filamentous fungi. Its use for this purpose has already been experimented and proven in previous researches (Bentubo et al, 2006) including for yeasts and in this same animal species (Bentubo et al, 2021) (Figure 1). By means of analyzing the macroscopic morphology of the isolates obtained in culture, it was possible to establish a correspondence with the probable genus of the filamentous fungus, as depicted in the taxonomic manuals utilized in this analysis. Riddel's (1950) technique of cultivation on slides, which was utilized for micro morphological visualization of the isolates, confirmed the suspicions regarding the identification of the isolates (Kurtzman \& Fell, 1998; De Hoog et al, 2004).

Figure 1. Utilization of the carpet square technique (Riddel, 1950 \& Bentubo et al, 2021) to obtain skin samples from giant anteaters (A) and anteaters (B) retained in captivity at Fundação Parque Zoológico de São Paulo (FPZSP) and Quinzinho de Barros Zoo (Zoo Sorocaba), Brazil.
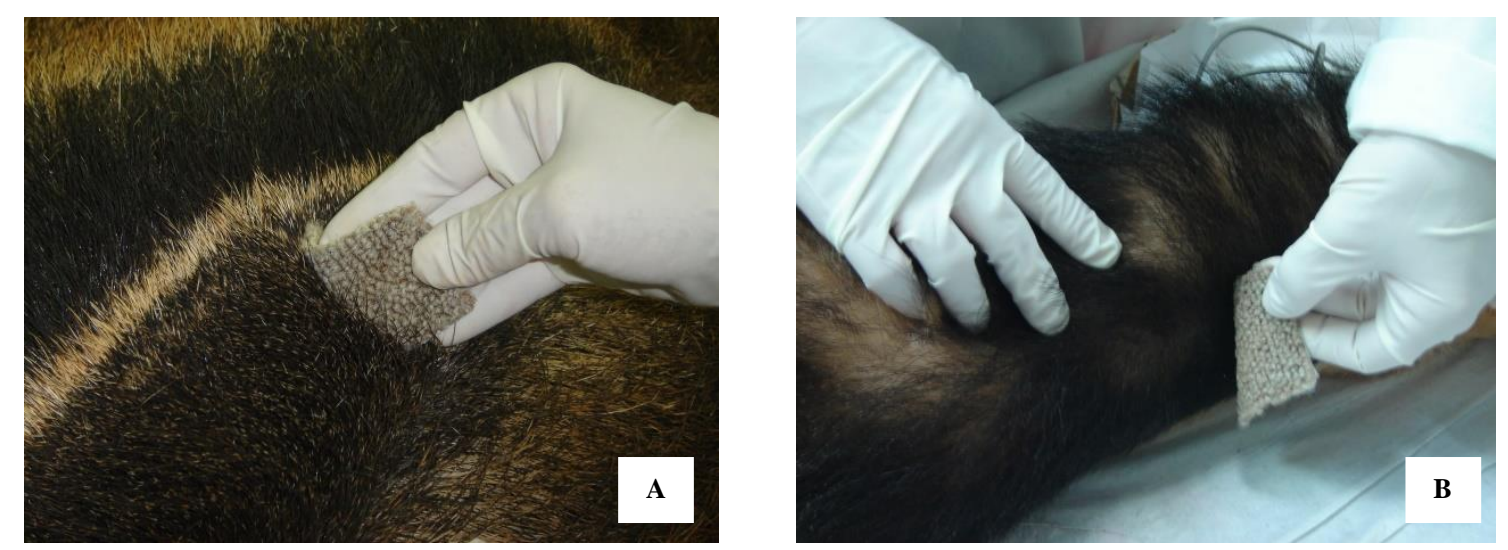

Source: Author's personal archive.

The main isolates of filament fungi found in the present investigation were Cladosporium spp. (51.8\%), Scopulariopsis sp (29.6\%), Aspergillus spp. (22.2\%), Acremonium spp., Chrysosporium spp. (11.1\%) and Mucor spp. (7.4\%) 
(Figure 2A). Dermatophytic fungi were not isolated from any of the animals studied; however, it was possible to isolate other keratinophilic genera from the coat of the studied anteaters. We highlight Scopulariopsis sp, Acremonium spp. and Chrysosporium spp. (Figure 2B). Initially, the morphological findings observed for the identification of these isolated genera will be discussed.

Figure 2. In "A", the frequency of genera of filamentous fungi; and in "B", that of non-dermatophytic filamentous fungi isolated from the tegument of giant anteaters and anteaters retained in captivity at Fundação Parque Zoológico de São Paulo (FPZSP) and Zoológico Quinzinho de Barros (Zoo Sorocaba), Brazil.
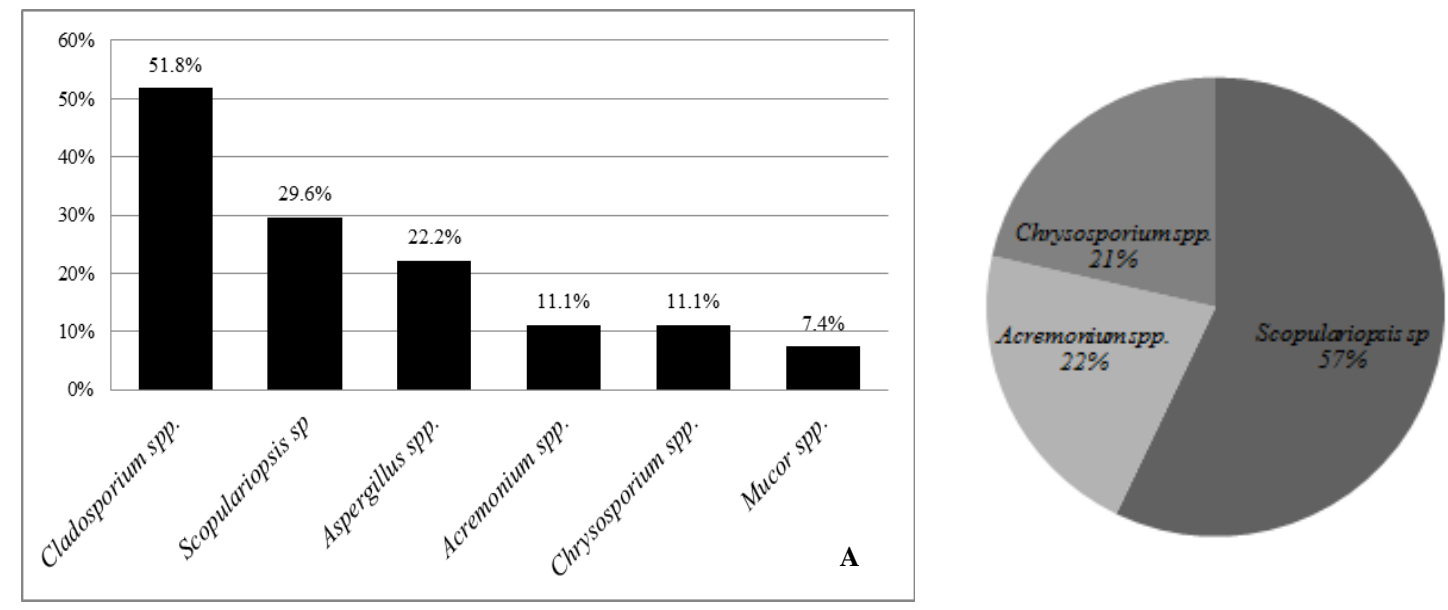

Source: Author's personal archive.

The isolate prevalent in this research, of the Cladosporium genus, is considered one of the most common filamentous fungi in the environment. These molds have a great capacity to colonize different substrates and are easy to grow in definitely limited environmental conditions (Gambale et al, 1993), for this reason they were additionally found in such a high frequency in the anteaters investigated in this research. They are considered among the fungi with the highest concentration in the atmosphere, mainly in tropical and sub-tropical climate regions (Zoppas et al, 2011). Menezes et al (2017) depicted the fungi of this genus as endowed with great adaptive capacity, capacity for contamination and colonization of different environments, as it was possible to verify in this study, where this genus was isolated from the integument of several species of anteater studied. As observed by means of other authors, in this research, the macro morphological evaluation of Cladosporium spp. demonstrated a naturally brownish coloration due to the presence of melanin pigment in its cell wall (Zaits et al, 2010 \& Sidrim \& Rocha, 2003).

Another genus of isolated fungi, Scopulariopsis sp, whose most common habitat is the soil, demonstrated a slow growth rate. Its macro morphological description was compatible with its sandy texture, velvety center and color that varied from white to beige. Both the macro and microscopic characteristics observed in the present research were compatible with those depicted in the literature (Sidrim \& Rocha, 2003; López-Jodra \& Torres-Rodrigues, 1999). The genus Aspergillus, the third most common filamentous fungus found in the normal anteater coat microbiota, is ubiquitous and can be isolated from definitely common places such as air, soil, water, food, plants, and a wide variety of inanimate surfaces (Ward et al, 2006). The isolates obtained in this research demonstrated a predominance of yellowish green coloration; however the literature considers that the genus can present colonies of green, yellow, brown and white coloration (Klich, 2002; Varga et al, 2004).

In this research, there was a prevalence of the genera Cladosporium spp. and Scopulariopsis sp. In a study carried out by means of Albano (2009), the genera Aspergillus and Scopulariopsis were found to be highly prevalent in the coat of felids, canids, marsupials, edentates, primates and rodents. Although the characteristics of the isolates obtained in this study are 
compatible with those found by means of Albano (2009), in no anteater there was any clinical manifestation of infection and the isolates only appeared to be part of the normal microbiota of the specimens studied. However, there are already references to the pathogenic power of these fungi.

Menezes et al (2017) reported in their research that the genus Cladosporium spp. it can cause from epithelial lesions, such as keratitis, with organ involvement, to the development of brain abscesses (Oliveira et al, 2001). Infections can progress to sepsis with consequent death in humans. In animals, it causes epithelial mycoses and fungal sinusitis in immunocompromised patients, the main causes being C. bantiana, C. carrioni and C. devriesii (Bensch et al, 2012). Scopulariopsis spp. pathogenic agents for animals and men are recognized (Filipello Marchisio et al, 2000; Nenoff et al, 2014), having already been observed acting as an etiological agent in dermatomycosis processes in domestic animals (Petanović et al, 2010). Ogawa et al (2008) reported a case of generalized infection by means of Scopulariopsis brevicaulis in a calf. The Aspergillus genus is known for its ability to produce toxic metabolites, well known in pathological processes called mycotoxicosis. These poisonings can affect animals and man. The best known mycotoxicosis is aflatoxicosis, a disease produced by means of aflatoxin, which is capable of developing respiratory conditions in the patient that can progress to sepsis in immunocompromised patients. These opportunistic conditions can even be associated with invasive pulmonary aspergillosis (Alves, 2017). Even in humans, there are descriptions in the literature in which the authors claim that aflatoxicosis can cause serious liver diseases, such as cancer, as aflatoxin has a necrotizing effect on this tissue (Oliveira \& Germano, 1997 \& Oliveira, 2016).

The pathogenesis of these fungal infections, when depicted in the literature, consists of mycotic skin diseases in humans and animals. Fungi found in animals can cause opportunistic mycotic infections, requiring monitoring for early diagnosis and control of these infections (Nobre et al, 1998, Naglik et al, 2004, Anaisse et al, 2009; Alves, 2017). At first, the simple presence of these fungi in the microbiota of the studied animals may not represent a health problem. However, when these findings are added to immunocompromising factors, the meaning of these findings may change. Inadequate maintenance in captivity, poor nutrition, unhealthy sanitary conditions, stress, prolonged antibiotic therapy, climatic factors such as humidity, $\mathrm{pH}$, temperature and type of substrate can be conditions that favor the prevalence and/or exaggerated proliferation of these agents that fabricate the normal microbiota of animals, taking these microorganisms from the commensal relationship to parasitism, when they can become pathogenic for their hosts.

The fungi of the genus Acremonium presented a macroscopic morphology slightly different from that observed in the previous isolates, forming colonies with a cottony appearance and white color with a slight pinkish hue in the center. That observation was not compatible with the description by means of Zhang et al (2012), who observed a slightly brownish hue in the isolates obtained in their research, something unusual for a hyaline fungus such as Acremonium spp. The microscopic morphology must present characteristics such as the presence of oval conidia, little elongated and even arcuate, with intercalated chlamydoconidia and septate hyphae. In this study, the isolates of Acremonium sp analyzed demonstrated definitely similar forms, with the exception of the chlamydoconidia (Novicki et al, 2003; Summerbell \& Schroers, 2002). Definitely contradictory references can be found in the scientific literature when we consider the pathogenicity of Acremonium spp. For example, Juarez et al (2007) reported the case of two patients with a history of gastric adenocarcinoma which were affected by means of the fungus through a parenteral feeding catheter and evolved without any clinical manifestation of opportunistic fungal infection. In contrast, Gòngora (2009) reported a case of infection by means of the Acremonium genus in which a patient from Mato Grosso do Sul (Brazil) developed a clinical picture of sinusitis that progressed to meningitis, which ended up causing the patient's death in less than one month of follow-up.

The genus Chrysosporium isolated in this microbiological investigation demonstrated white and opaque cotton colonies with a light brown reverse. The microscopic analysis demonstrated the presence of typical linear septate hyphae, 
branched, with thick-walled globose microconidia. There are few reports in the literature of infection by means of the Chrysosporium genus; however this genus appears to have a relevant importance for the medical clinic of reptiles (Cabañes et al, 2014). Vissiennon et al (1999) reported a case in the literature of disseminated infection by means of the Chrysosporium queenslandicum in a snake (genus Thamnophis). Thomas et al (2002) reported a case of cutaneous infection by means of the Chrysosporium sp in a saltwater crocodile (Crocodylus porosus). And, Delgado et al (2017) depicted a case of fungal dermatitis caused by means of the Chrysosporium spp. in specimen of green iguana (Iguana iguana) in Argentina. Interestingly, both in the case of Thomas et al (2002) and Delgado et al (2017) the infection affected the skin; however it proved fatal in the case of the crocodile. Since the management of a gigantic and dangerous prehistoric reptile in captivity is extremely delicate, perhaps the difference between the prognosis observed for crocodile and the iguana perhaps was associated with the early diagnosis in the iguana.

The genus isolated with less frequency in the present research was the genus Mucor. In culture, the isolate demonstrated exuberant growth on the plate. The colony had a cottony, soft appearance; initially yellowish white color, which with maturity turned dark gray. Microscopically, the isolates had sporangiophores that were erect and were simple or branched and globose. These characteristics are compatible with those depicted by means of Alves et al (2002). Infections caused by means of zygomycetes may have different epidemiological characteristics, depending on the Order to which they belong. Those belonging to the Orderm Entomoftorales usually affect immunocompetent individuals. The Order Mucorales are most commonly associated with infection in immunocompromised patients. In the case report by means of Xavier (2004), a decompensated diabetic patient who was affected by means of Mucor sp developed fungal sinusitis and consequent rhinocerebral mucormycosis. In this case, surgical intervention and systemic treatment with Amphotericin B were necessary to control the infection. However, there are researchers who alert to the possibility that the fungus additionally affects immonocompetent individuals (Santana et al, 2001).

\section{Final Considerations}

Through the present investigation, it was possible to conclude that non-dermatophytic keratinophilic fungi colonize the coat surface of giant anteaters and baby anteaters retained in captivity. Therefore, the staff involved with the maintenance of these animals must be aware of the predisposing factors for opportunistic infection for animals in captivity and examinations with the purpose of monitoring, both the environment and the animals inserted in them, must be carried out thus that it is possible to attribute a predictive character of infections when the risks are present in the context. The negative result for dermatophyte fungi should not be understood as an immutable condition, since the conditions found in this research were quite limited, not including such a wide sampling or the diversity found in a country with continental dimensions like Brazil. Future research should consider different environments, including free-living, as well as little-studied species such as the silky anteater (Cyclopes didactylus), a species not included in this investigation.

\section{Acknowledgment}

To Vice-Reitoria de Pós-Graduação e Pesquisa of Universidade Paulista (UNIP). São Paulo. SP. Brazil.

\section{References}

Acco, A., Pachaly, J. R., \& Bacila, M. (1999). Síndrome do estresse em animais-Revisão. Arquivos de Ciências Veterinárias e Zoologia da UNIPAR, 2(1).

Albano, A. P. N., Mendes, J. F., Felicio, A. P., Coimbra, M. A. A., Leite, A. T. M., Minello, L. F., \& Meireles, M. C. A. (2011). Microbiota fungica de felideos silvestres hígidos encaminhados a centros de triagem no Rio Grande do Sul e Mato Grosso do Sul. Rev Cient Med Vet, 9, 654-658.

Albano, A. P. N. (2009). Fungos e micoses em animais silvestres recebidos por Centros de Triagem (Master's thesis, Universidade Federal de Pelotas). 
Alves, M. H., Trufem, S. F., \& Milanez, A. I. (2002). Táxons de Mucor Fresen.(Zygomycota) em fezes de herbívoros, Recife, PE, Brasil. Brazilian Journal of Botany, 25, 147-160.

Alves, P. D. M. (2017). Rastreio de fungos patogénicos e oportunistas em animais domésticos, selvagens e em humanos: implicações na saúde pública (Master's thesis).

Amaral, C. D. P. D., Pereira, D. I. B., \& Meireles, M. C. A. (2011). Caracterização da microbiota por fungos filamentosos no tegumento hígido de bovinos de corte. Ciência Rural, 41, 2137-2142.

Anaissie, E. J., McGinnis, M. R., \& Pfaller, M. A. (2009). Clinical Mycology E-Book. Elsevier Health Sciences.

Benites, M., \& Mamede, S. B. (2008). Mamíferos e aves como instrumentos de educação e conservação ambiental em corredores de biodiversidade do Cerrado, Brasil. Mastozoología neotropical, 15(2), 261-271.

Bentubo, H. D. L., Fedullo, J. D. L., Corrêa, S. H. R., Teixeira, R. H. F. \& Coutinho, S. D. (2006). Isolation of Microsporum gypseum from the haircoat of helth wild felids kept in captivity in Brazil. Braz J Microbiol, 37, 148- 152

Bentubo, H. D. L., Miranda, F. R., Paula, C. D. de, \& Coutinho, S. D. (2021). Isolamento de leveduras patogênicas da microbiota superficial de tamanduás mantidos em cativeiro. Research, Society and Development, 10(17), e53101724390.

Bensch, K., Braun, U., Groenewald, J. Z., \& Crous, P. W. (2012). The genus Cladosporium. Studies in mycology, 72, 1-401.

Bispo, D. L. N., \& Pereira, O. C. M. (1994). Importância do conhecimento das alterações induzidas pelo estresse, em animais domésticos. Interciência, 19(2), $72-74$.

Borges, L. A. C., Rezende, J. L. P. D., Pereira, J. A. A., Coelho Júnior, L. M., \& Barros, D. A. D. (2011). Áreas de preservação permanente na legislação ambiental brasileira. Ciência Rural, 41(7), 1202-1210.

Braga, F. G. (2010). Ecologia e comportamento de tamanduá-bandeira Myrmecophaga tridactyla Linnaeus, 1758 no município de Jaguariaíva, Paraná. Carramenha, C. P., \& Carregaro, A. (2012). Estresse e morte súbita em Medicina Veterinária. Ars Vet., 90-99.

Cabañes, F. J., Sutton, D. A., \& Guarro, J. (2014). Chrysosporium-related fungi and reptiles: a fatal attraction. PLoS pathogens, $10(10)$, e1004367.

Chebez, J. C., \& Bertonatti, C. (1994). Los que se van: especies argentinas en peligro. Editorial Albatros.

Cornejo-Juárez, P., Velásquez-Acosta, C., Martínez-Roque, V., Rangel-Cordero, A., \& Volkow-Fernández, P. (2007). Fungemia asintomática causada por Acremonium sp asociada a colonización de catéter venoso central (CVC). Gaceta Médica de México, 143(3), 193-196.

Cubas, Z., Silva, J., \& Catão-Dias, J. L. (2014). Tratado de animais selvagens: medicina veterinária.

De Hoog, G. S., Guarro, J., Gené J. \& Figueiras, M. J. (2004). Atlas of Clin.Fungi. (No. Ed. 2), Ultrech \& Réus: Centralbureal voor Schimmelcultures to IUniversitat Rovira, Virgilli.

Delgado, A. R., Lorente, J. A., Troiano, J. C., \& Rejf, P. K. (2017). Isolamento de Chrysosporium spp. em dermatite em Iguana iguana-primeiro relato na Argentina. Clín. Vet., 82-85.

Drumond, M. A., de Barros, N. F., de Souza, A. L., da Silva, A. F., \& Teixeira, J. L. (1997). Composição mineral e demanda nutricional de espécies florestais da Mata Atlântica. Embrapa Semiárido-Artigo em periódico indexado (ALICE).

Emmons, L., \& Feer, F. (1997). Neotropical rainforest mammals: a field guide (No. Sirsi) i9780226207193).

Filipello Marchisio, V., Fusconi, A., \& Querio, F. L. (2000). Scopulariopsis brevicaulis: a keratinophilic or a keratinolytic fungus? Mycoses, 43(7-8), 281-292.

Franci, O., Amici, A., Margarit, R., Merendino, N., \& Piccolella, E. (1996). Influence of thermal and dietary stress on immune response of rabbits. Journal of animal science, 74(7), 1523-1529.

Fundação Zoo-Botânica. Reconhecimento na preservação de espécies ameaçadas de extinção. <http://portalpbh.pbh.gov.br/pbh/contents.do?evento=conteudo \&idConteudo=28201\&chPlc=28201>. Access: Jun22th 2017 .

Gambale, W., Croce, J., Costa-Manso, E., Croce, M., \& Sales, M. (1993). Library fungi at the University of São Paulo and their relationship with respiratory allergy. Journal of investigational allergology \& clinical immunology, 3(1), 45-50.

Gòngora, D. V. N.de, Soares, M. M. C. N., dos Santos David, P. R., Nogueira, M. C. L., \& de Almeida, M. T. G. (2009). Chronic meningitis by Acremonium sp. Revista de Ciências Médicas e Biológicas, 8(3), 347-350.

IBAMA. Sobre o Ibama. 2017. 〈http://www.ibama.gov.br/institucional/ sobre-o-ibama/sobre-o-ibama-historico\#historico〉.

Ishikawa, M. M., Lucas, R., Larsson, C. E., Gambale, W., \& Fernandes, W. R. (1996). Isolamento e identificação da microbiota fúngica e de dermatófitos da pele de equinos hígidos e daqueles afetados por dermatofitose. Brazilian Journal of Veterinary Research and Animal Science, 33(3), 170-175.

IUCN. International Union for Conservation of Nature. (2021). The IUCN red list of threatened species. <www.https://www.iucnredlist.org/> .

Klich, M. A. (2002). Identification of common Aspergillus species. CBS. 
Klink, C. A., \& Machado, R. B. (2005). Conservation of the brazilian cerrado. Conservation biology, 19(3), 707-713.

Kurtzman, C., Fell, J. W. \& Boekhout, T. (Eds.). (2011). The yeasts: a taxonomic study. Elsevier.

Lacaz, C. D. S., Porto, E., Martins, J. E. C., Heins-Vaccari, E. M., \& Takahashi de Melo, N. (2002). Tratado de micologia médica.

Lewinsohn, T. M., \& Prado, P. I. (2005). Quantas espécies há no Brasil. Megadiversidade, 1(1), 36-42.

López-Jodra, O., \& Torres-Rodríguez, J. M. (1999). Especies fúngicas poco comunes responsables de onicomicosis. Rev Iberoam Micol, 16(1), 11-15.

Mariat, F. \& Adam-Campos, C. (1967). La technique du carré du tapis, méthode simple de prélevement dans les mycoses superficielles. Ann Inst Pasteur, 113, 666-668.

Medri, I. M., Mourão, G., \& Harada, A. Y. (2003). Dieta de tamanduá-bandeira (Myrmecophaga tridactyla) no Pantanal da Nhecolândia, Brasil. Edentata, 5, $29-34$.

Menezes, C. P., de Lima Perez, A. L. A., \& Oliveira, E. L. (2017). Cladosporium spp.: morfologia, infecções e espécies patogênicas. Acta Brasiliensis, 1(1), $23-27$.

MMA. Ministério do Meio Ambiente. (2002). Avaliação e identificação de áreas e ações prioritárias para a conservação, utilização sustentável e repartição dos benefícios da biodiversidade nos biomas brasileiros.

Miranda, F., Fallabrino, A., Arteaga, M., Tirira, D. G., Meritt, D. A., \& Superina, M. (2014). Tamandua tetradactyla. The IUCN Red List of Threatened Species, 2014, T21350A47442916.

Montgomery, G. G. (1985). Movements, foraging and food habits of the four extant species of neotropical vermilinguas (Mammalia; Myrmecophagidae).

Morton, D. J., Anderson, E., Foggin, C. M., Kock, M. D., \& Tiran, E. P. (1995). Plasma cortisol as an indicator of stress due to capture and translocation in wildlife species. The Veterinary Record, 136(3), 60-63.

Naglik, J., Albrecht, A., Bader, O., \& Hube, B. (2004). Candida albicans proteinases and host/pathogen interactions. Cellular microbiology, 6(10), 915-926.

Nakajima, J. N., Junqueira, T. V., Freitas, F. S., \& Teles, A. M. (2012). Comparative analysis of red lists of the Brazilian flora: Asteraceae. Rodriguésia, 63, 039-054.

Nenoff, P., Krüger, C., Ginter-Hanselmayer, G., \& Tietz, H. J. (2014). Mycology-an update. Part 1: Dermatomycoses: causative agents, epidemiology and pathogenesis. JDDG: Journal der Deutschen Dermatologischen Gesellschaft, 12(3), 188-210.

Nobre, M., Meireles, M., Gaspar, L. F., Pereira, D., Schramm, R., Schuch, L. F., ... \& Souza, L. (1998). Malassezia pachydermatis e outros agentes infecciosos nas otites externas e dermatites em cães. Ciência rural, 28, 447-452.

Nowak, R. M. (2018). Walker's mammals of the world: monotremes, marsupials, afrotherians, xenarthrans, and sundatherians. JHU Press.

Novicki, T. J., LaFe, K., Bui, L., Bui, U., Geise, R., Marr, K., \& Cookson, B. T. (2003). Genetic diversity among clinical isolates of Acremonium strictum determined during an investigation of a fatal mycosis. Journal of Clinical Microbiology, 41(6), 2623-2628.

Ogawa, S., Shibahara, T., Sano, A., Kadota, K., \& Kubo, M. (2008). Generalized hyperkeratosis caused by Scopulariopsis brevicaulis in a Japanese black calf. Journal of comparative pathology, 138(2-3), 145-150.

Oliveira, C. A. F. D., \& Germano, P. M. L. (1997). Aflatoxinas: conceitos sobre mecanismos de toxicidade e seu envolvimento na etiologia do câncer hepático celular. Revista de Saúde Pública, 31, 417-424.

Oliveira, E. D. (2016). Hematologia, Bioquímica e eletroforese de proteínas séricas de Tamanduás-bandeiras (Myrmecophaga tridactyla, Linnaeus, 1758) em cativeiro.

Oliveira, P. R. D., Resende, S. M., Oliveira, F. C. D., \& Oliveira, A. C. D. (2001). Ceratite fúngica. Arquivos Brasileiros de Oftalmologia, 64, 75-79.

Paula, É. J. de, Plastino, E. M., de Oliveira, E. C., Berchez, F., Chow, F., \& de Oliveira, M. C. (2007). Introdução à biologia das criptógamas. São Paulo: Instituto de Biociências da Universidade de São Paulo.

Peres, M. B., Vercillo, U. E., \& de Souza Dias, B. F. (2011). Avaliação do Estado de Conservação da Fauna Brasileira e a Lista de Espécies Ameaçadas: o que significa, qual sua importância, como fazer?. Biodiversidade Brasileira-BioBrasil, (1).

Petanović, M., Tomić Paradžik, M., Krištof, Ž., Cvitković, A., \& Topolovac, Z. (2010). Scopulariopsis brevicaulis as the cause of dermatomycosis. Acta Dermatovenerologica Croatica, 18(1), 0-0.

Projeto Tamanduá. (2015). QUEM somos? <http://tamandua.org/2016/quemsomos.html>

Rambaldi, D. M., \& Oliveira, D. D. (2005). Fragmentação de ecossistemas: causas, efeitos sobre a biodiversidade e recomendações de políticas públicas (p. 510). Secretaria de Biodiversidade e Florestas.

Ribeiro-Júnior, J. W., \& Bertoluci, J. (2009). Anurans of the cerrado of the Estação Ecológica and the Floresta Estadual de Assis, southeastern Brazil. Biota Neotropica, 9(1), 0-0.

Riddell, R. W. (1950). Permanent stained mycological preparations obtained by slide culture. Mycologia, 42(2), 265-270. 
Rocha, L. F. N. (2010). Caracterização morfológica, molecular e biológica de fungos patogênicos a invertebrados dos Cerrados de Goiás.

Rosa, A. L. M. (2007). Efeito da temperatura ambiental sobre a atividade, uso de habitat e temperatura corporal do tamanduá-bandeira (Myrmecophaga tridactyla) na fazenda Nhumirim, Pantanal.

Rossoni, R. B., Machado, C. R., \& Machado, A. B. (1981). Autonomic innervation of salivary glands in the armadillo, anteater, and sloth (Edentata). Journal of morphology, 168(2), 151-157.

Santana, N. O., Pinheiro, G. B., Kehrle, H. M., Faria, I. P. D., \& Estrella, C. N. (2001). Mucormicose de seios paranasais e órbitas em paciente imunocompetente: relato de caso e revisão de literatura. Revista Brasileira de Otorrinolaringologia, 67, 727-730.

Shaw, J. H., Carter, T. S., \& Machado-Neto, J. C. (1985). Ecology of the giant anteater Myrmecophaga tridactyla in Serra da Canastra, Minas Gerais, Brazil: a pilot study.

Sidrim, J. J. C., \& Rocha, M. F. G. (2004). Micologia médica à luz de autores contemporâneos. Guanabara Koogan.

Summerbell, R. C., \& Schroers, H. J. (2002). Analysis of phylogenetic relationship of Cylindrocarpon lichenicola and Acremonium falciforme to the Fusarium solani species complex and a review of similarities in the spectrum of opportunistic infections caused by these fungi. Journal of Clinical Microbiology, 40(8), 2866-2875.

Teta, P., Abba, A. M., Cassini, G. H., Flores, D. A., Galliari, C. A., Lucero, S. O., \& Ramírez, M. (2018). Lista revisada de los mamíferos de Argentina. Mastozoología Neotropical, 25(1), 163-198.

Thomas, A. D., Sigler, L., Peucker, S., Norton, J. H., \& Nielan, A. (2002). Chrysosporium anamorph of Nannizziopsis vriesii associated with fatal cutaneous mycoses in the salt-water crocodile (Crocodylus porosus). Medical mycology, 40(2), 143-151.

Varga, J., Juhász, Á., Kevei, F., \& Kozakiewicz, Z. (2004). Molecular diversity of agriculturally important Aspergillus species. Molecular Diversity and PCRdetection of Toxigenic Fusarium Species and Ochratoxigenic Fungi, 627-640.

Varo, S. D., Martins, C. H. G., Cardoso, M. J. D. O., Sartori, F. G., Montanari, L. B., \& Pires-Gonçalves, R. H. (2007). Isolamento de fungos filamentosos em água utilizada em uma unidade de hemodiálise. Revista da Sociedade Brasileira de Medicina Tropical, 40, $326-331$.

Vié, J. C., Hilton-Taylor, C., \& Stuart, S. N. (Eds.). (2009). Wildlife in a changing world: an analysis of the 2008 IUCN Red List of threatened species. IUCN.

Vieira, C. (1949). Xenartros e marsupiais do Estado de São Paulo. Arquivos de Zoologia, 7(3), 325-362.

Vissiennon, T., Schüppel, K. F., Ullrich, E., \& Kuijpers, A. F. (1999). Case report. A disseminated infection due to Chrysosporium queenslandicum in a garter snake (Thamnophis). Mycoses, 42(1-2), 107-110.

Ward, O. P., Qin, W. M., Dhanjoon, J., Ye, J., \& Singh, A. (2005). Physiology and biotechnology of Aspergillus. Advances in applied microbiology, 58, 1-75.

Xavier, S. D., Korn, G. P., \& Granato, L. (2004). Mucormicose rinocerebral: apresentação de caso com sobrevida e revisão de literatura. Revista Brasileira de Otorrinolaringologia, 70, 710-714.

Zaitz, C., Campbell, I., Marques, S. A., Ruiz, L. R. B., \& Souza, V. M. D. (1998). Compêndio de micologia médica. In Compendio de Micologia Medica (pp. 434-434).

Zhang, S., Corapi, W., Quist, E., Griffin, S., \& Zhang, M. (2012). Aspergillus versicolor, a new causative agent of canine disseminated aspergillosis. Journal of clinical microbiology, 50(1), 187-191.

Zimbres, B. D. Q. C. (2010). Efeito da fragmentação sobre a comunidade de tatus e tamanduás (Mammalia: Xenarthra) no Cerrado brasileiro: uma abordagem da ecologia de paisagens.

Zoppas, B. C. D. A., Valencia-Barrera, R. M., \& Fernández-Gonzáles, D. (2011). Distribuição de esporos de Cladosporium spp. no ar atmosférico de Caxias do Sul, RS, Brasil, durante dois anos de estudo. Rev. bras. alergia imunopatol, 55-58. 